\title{
GIS-based Geotechnical Microzonation Mapping using Analytic Hierarchy Process: a case study in Shire-Endasilasie City, Tigray, Northern Ethiopia
}

\section{Shishay Tadios}

Department of Earth Sciences, college of Natural and Computational Sciences, P.O.Box 231, Mekelle University, Ethiopia (sisayk2007@gmail.com)

\begin{abstract}
This study deals with the development of a Geographic Information System (GIS)-based geotechnical microzonation model/map using Analytic Hierarchy Process (AHP) for ShireEndasilasie, a rapidly growing city in Tigray, northern Ethiopia. The influencing factors considered as inputs for the development of the model are (i) slope gradient, (ii) bed rock and soil type, (iii) swelling potential of soil and (iv) depth to groundwater level. The factors and the classes within each factor are assigned weight and rank values respectively. To avoid subjectivity, the assignment of weight and rank values and the analysis are done by the application of AHP method. From the weight and rank values of the layers, geotechnical suitability indices were calculated using a Weighted Linear Combination (WLC) model in GIS. These continuous numerical index values have been divided into different classes. The classification result implies that the less suitable zone represents the areas that require a detailed geotechnical investigation, the moderately suitable zone represents a provisional settlement area, and the suitable zone represents the areas that are best suitable for settlement.
\end{abstract}

Keywords: GIS, Analytic Hierarchy Process; Geotechnical microzonation model; Foundation, Shire-Endasilasie, Tigray, Ethiopia.

\section{INTRODUCTION}

Shire-Endasilasie is one of the rapidly growing cities in Tigray region, northern Ethiopia and currently the construction work is being undertaken in a big way in all directions of the city. As a result of increase in population, there is a demand of new areas for residential purpose. As a result, people are moving to the hillsides and previous farm lands on the city sides and are constructing several residential buildings without going through the planning stage and without undertaking evaluation of geological and geotechnical factors which is essential to determine the suitability of the foundation of residential areas (Khizar, 2003). According to the field observation and information obtained from personal communication with a city planner from the City Municipality Bureau, it is not uncommon to see the geotechnical- related problems associated with the already constructed buildings and also on the ongoing construction activities in the city. The problems that commonly observed and reported are: (a) buildings showing vertical displacement and development of cracks in the walls; (b) difficulties in 
construction/excavation activities due to shallow groundwater, and (c) damages caused due to frequent flooding.

Several authors (Belton and Stewart, 2002; Dai et al., 2001; Sun, 2010; Kolat, 2012; Sener et al., 2006; Sugen and Doyuran, 2004) have indicated the need for a systematic study and evaluation of parameters that are important for different multivariate decision making tasks using GIS-based analysis. Some studies (Tonkin \& Taylor. 2008; Cavaleiro et al., 2006; Roch, 2000; Khizar, 2003; Carrara et al., 1999; Jankowski, 1995) have also mentioned that in the preparation of geotechnical maps and plans related to engineering problems, and for proper handling of large volumes of information related to geotechnical data, the use of software such as the Geographical Information Systems (GIS) has become an inevitable tool. In one of the studies, Khizar (2003) has stressed the need of geotechnical evaluation to determine the suitability of the foundation of residential areas and to ensure the stability/safety of any building in an area. Furthermore, it is also stated that the areas where the settlements are high and dense prior to geotechnical evaluation, preparation of geotechnical microzonation model helps to check the suitability of the area for such density and also to determine the precautions that are needed for safer planning actions or modifications.

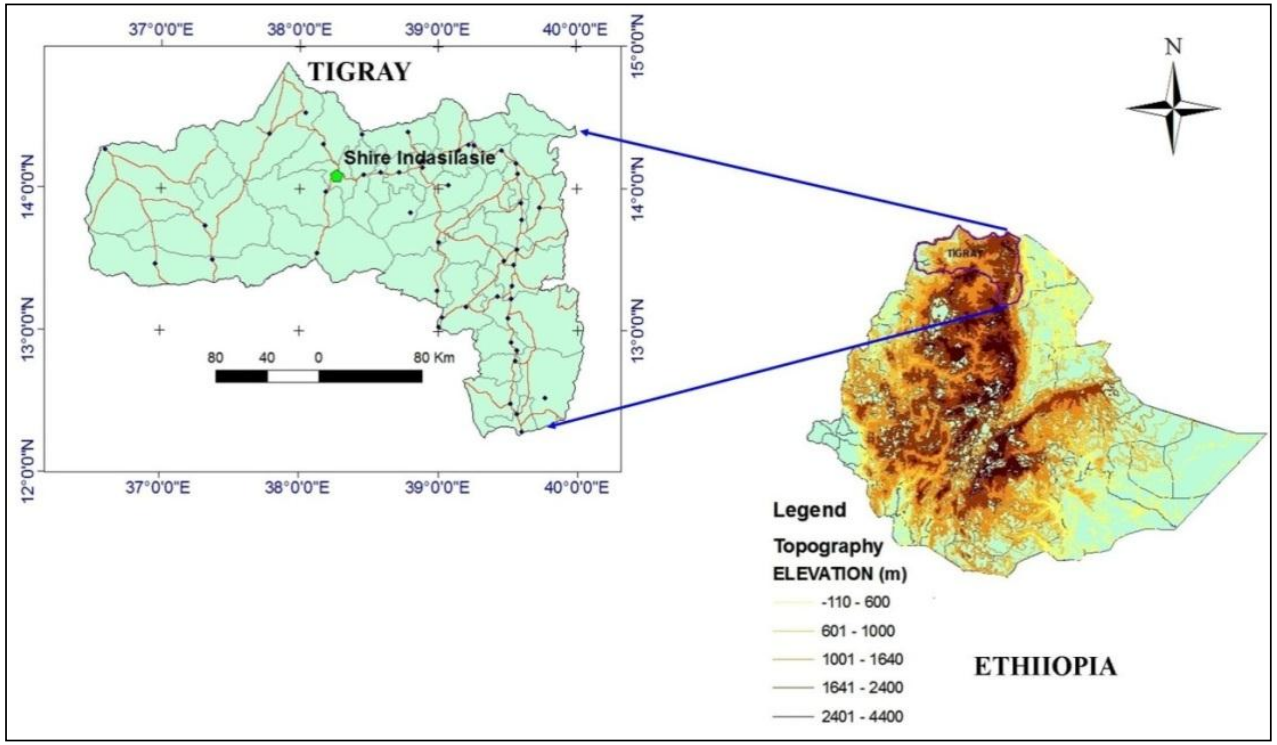

Figure 1. Location map of Shire-Endasilasie.

Based on the above, the present paper proposes a geotechnical microzonation model for ShireEndasilasie city using GIS-based multi-criteria decision analysis (particularly AHP). It includes 
(a) preparation of a geotechnical microzonation model, (b) producing a concise flowchart for geotechnical microzonation process, and (c) checking its suitability.

\section{ABOUT THE STUDY AREA}

\subsection{Location, topology and climate}

Shire-Endasilasie city is located in the northwestern zone of Tigray Regional State, northern Ethiopia (Fig1) and geographically it is bounded between $14^{\circ} 04^{\prime} 55^{\prime \prime} \mathrm{N}$ to $14^{\circ} 07^{\prime} 00^{\prime \prime} \mathrm{N}$ latitude, and $38^{\circ} 15^{\prime} 30^{\prime \prime E}$ to $38^{\circ} 19^{\prime} 00^{\prime \prime} E$ longitude. It covers an area of about $21.6 \mathrm{sq} . \mathrm{km}$. The topography of the study area is mainly flat in the central part, bounded by large hills in the northern part, small hills in the southern and western parts, and river in the eastern part of the city (Fig 2). The pattern of rainfall regime of the area is unimodal with mean annual rainfall of 900-1200mm and the annual average temperature between $21.5-23.5^{\circ} \mathrm{C}$ (Anon, 1995).

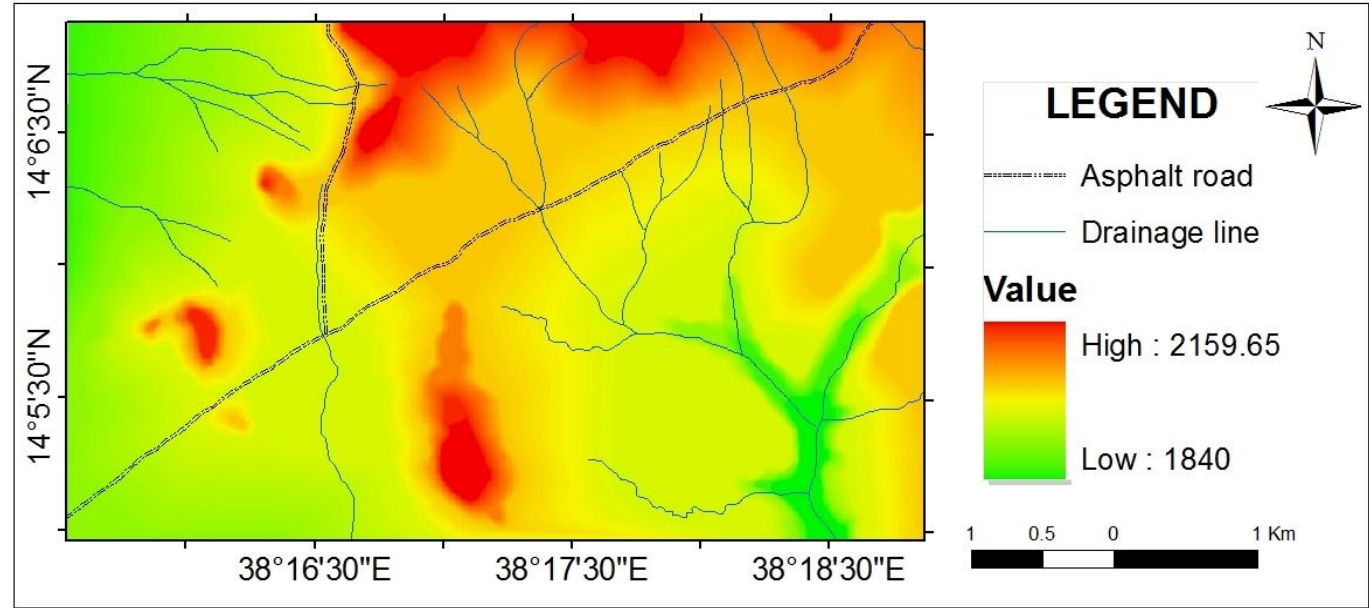

Figure 2. Digital Elevation Model (DEM) of Shire-Endasilasie.

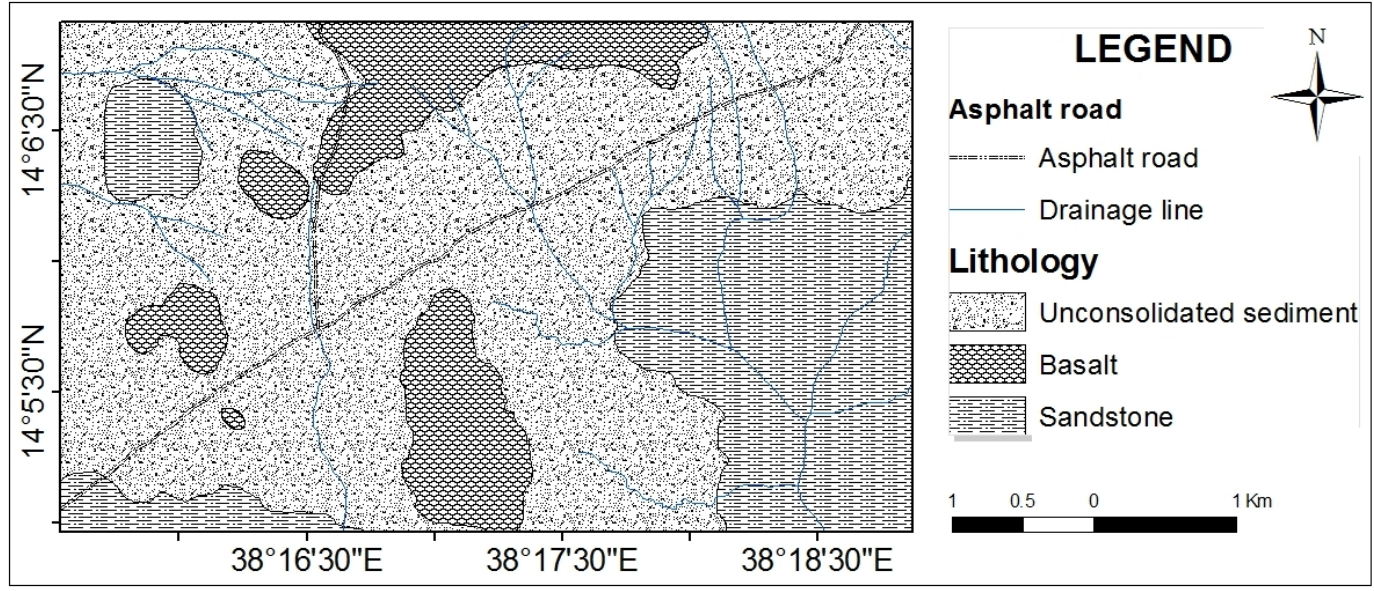

Figure 3. Geological map of Shire-Endasilasie. 


\subsection{Geology}

The study area is mainly covered by sandstone, Tertiary volcanics and unconsolidated sediments

(Fig 3). The sandstone consists of intercalations of sandstone and siliceous mudstone with thin lateritic cover, and is correlated with the Adigrat Sandstone (Tarekegn, 1997).

\section{METHODOLOGY}

The methodology used in this study is shown in the flow chart (Fig 4).

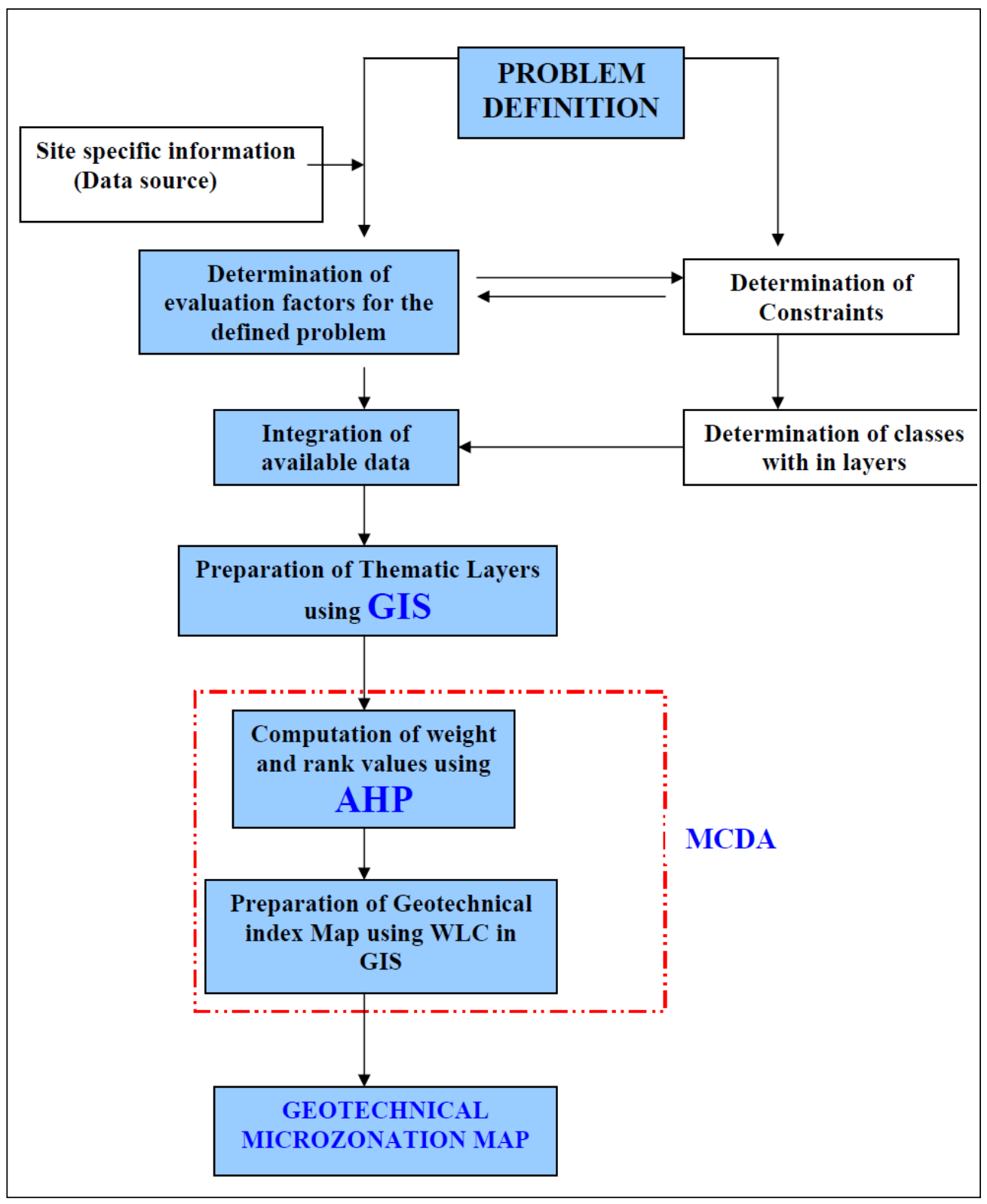

Figure 4. Flowchart of the research methodology. 


\subsection{Evaluation of Geotechnical and Related Factors}

The geotechnical and related factors in the study area have been assessed through field investigation and existing data evaluation. The assessment was mainly geared towards identification and characterization of major factors that influence the suitability of foundations of the residential areas. The input data sources used to generate the geotechnical and related factors are topographic maps, geological map and data from test pits and existing water wells together with field investigation and verification. The major geotechnical factors that are considered to be influencing the degree of suitability of the area as residential site are: slope gradient, soil type, swelling potential of soils, depth to groundwater table and flood susceptibility. The details of the data acquisition and evaluation of the above mentioned factors are given below.

\subsubsection{Slope gradient}

A digital elevation model (DEM) representing the terrain is a key to derive slope map, which influences the geotechnical and geo-environmental condition in an area. Hence, DEM (pixel size $10 \mathrm{~m}^{*} 10 \mathrm{~m}$ ) of the study area was generated (Fig3) by digitizing contour lines of a topographic map (1:50,000 scale) of 40 meter contour interval. The DEM was used to investigate the topography of the study area and to derive slope (gradient) map of the area using ArcGIS 9.1.The main limitation from using this topographic map for the derivation of DEM is the limited resolution of topography because $40 \mathrm{~m}$ contour interval is used, however, with a closer contour interval, slope gradients could be more accurately represented.

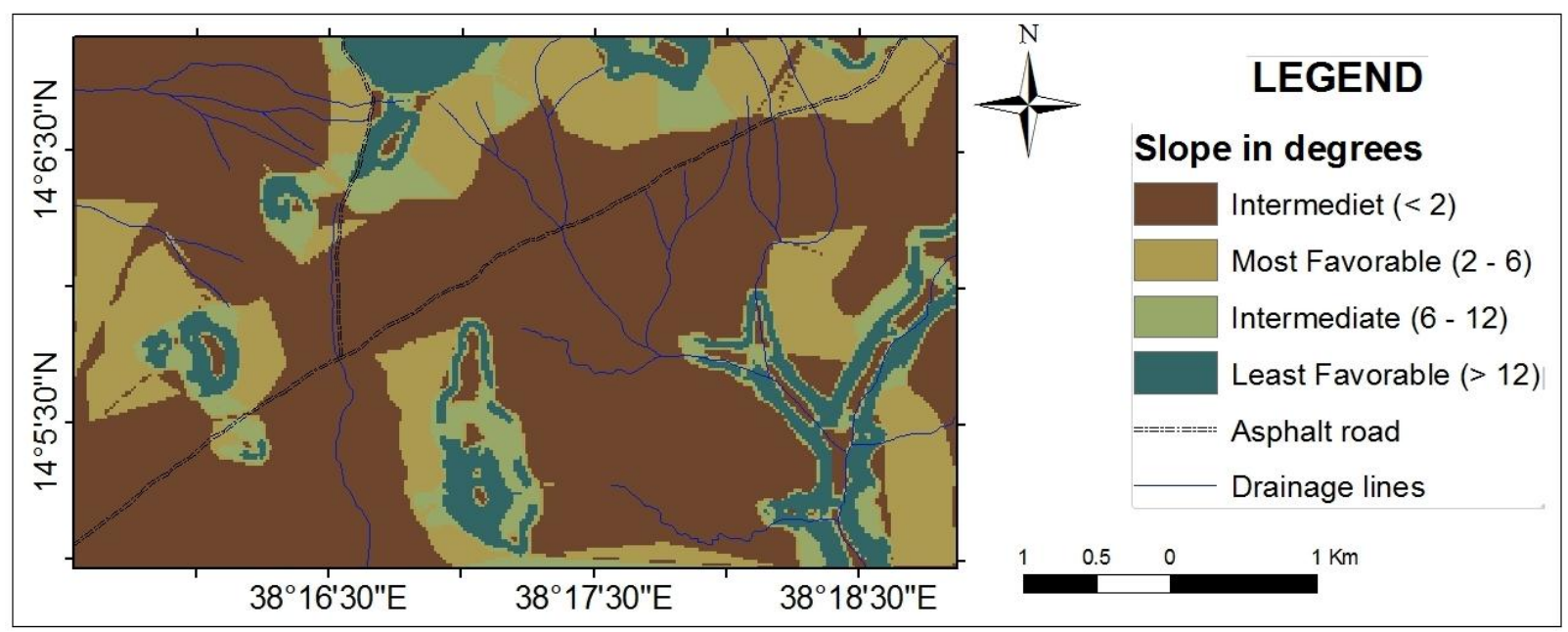

Figure 5. Slope gradient map.

Slope is an important parameter while considering the ease of engineering construction and susceptibility to slope instability (Dai et al., 2001). From field observation and previous studies 
in the area, there is no threat of landslide hazard. Hence, the consideration of slope gradient with respect to its influence to landsliding is not significant. However, it has an influence on the geotechnical microzonation map with respect to the ease of engineering constructions, due to the fact that high slope gradient implies increasing difficulties and costs of excavation processes.

The slope gradient map (Fig 5) was prepared in degrees and its values were subdivided into three main classes according to the Guidelines for Urban Engineering Geological Investigations (Stiff et al., 1997). These classes are grouped as follows: i) slopes between $2^{\circ}$ and $6^{\circ}$ in the most favorable class, ii) slopes less than $2^{\circ}$ and slopes between $6^{\circ}$ and $12^{\circ}$ in the intermediate class and iii) slopes greater than $12^{\circ}$ in the least favorable class

\subsubsection{Bed rock and Soil types}

The soil layer of the study area is based on the lithological map and data gathered from different pits and trenches. The dominating lithologies in the area are basalt, sandstone and unconsolidated sediments. For many structures founded on bed rocks, loads are well within the elastic limit of the rock mass and with respect to this study it is not necessary to consider the bed rock types separately. Hence the different rock types are considered all together as bed rock. Further investigation on the unconsolidated sediments is done to prepare the soil map layer of the area. Soils from different test pits in the area have been collected and evaluated considering the depth range corresponding to the average foundation excavations. Particle size distribution analysis and atterberg limit test on representative soil samples were done. Liquid limit and plasticity index data were compiled and the data were plotted into the plasticity chart in order to classify the soil.

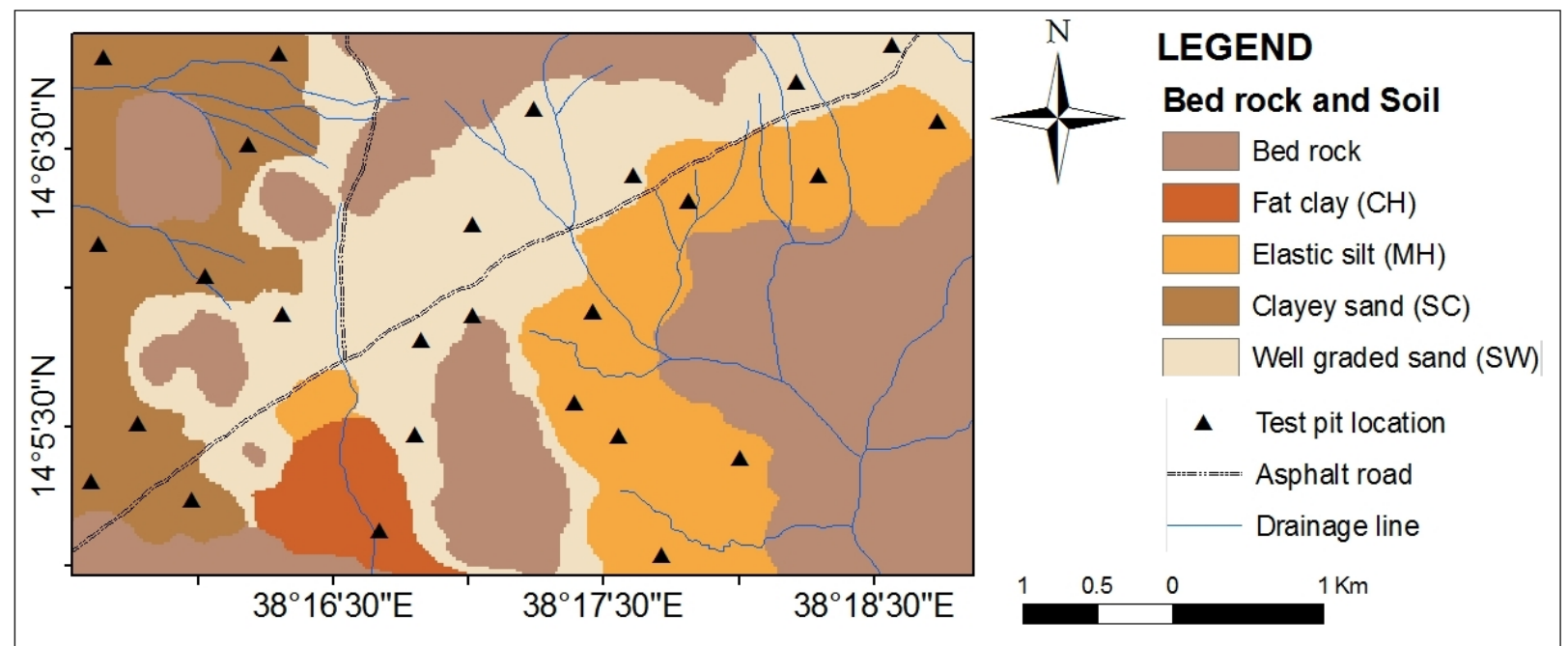

Figure 6. Bed rock and soil type map. 
The soil map is prepared based on the Unified Soil Classification System (USCS) and according to which, the main soil classes are: $\mathrm{CH}$ (Inorganic clays of high plasticity, fat clays), SC (Clayey sands, sand-clay mixtures), SW (well graded sand), and GW (well graded gravel). Together with the visual field observation, the soil test results were evaluated spatially and the boundaries of the soil classes were determined manually. The bed rock and soil map of the study area including the test pit locations is given in figure 6.

\subsubsection{Swelling potential of soils}

The other geotechnical factor affecting the suitability of an area as residential site is the swelling potential of soils. The swelling potential layer of the study area was determined through analysis of soil samples taken from test pits for the first $2.5 \mathrm{~m}$ from the surface, since below this depth the soil moisture remains constant.

After compiling the clay content $(\%)$ and plasticity index $(\%)$ of the soils from the test pits within $0-2.5 \mathrm{~m}$ depth interval, these values were evaluated by using activity chart. The result was found to be within the low, medium and high expansion classes and the bed rock is also considered as one class with no expansion (Fig 7).

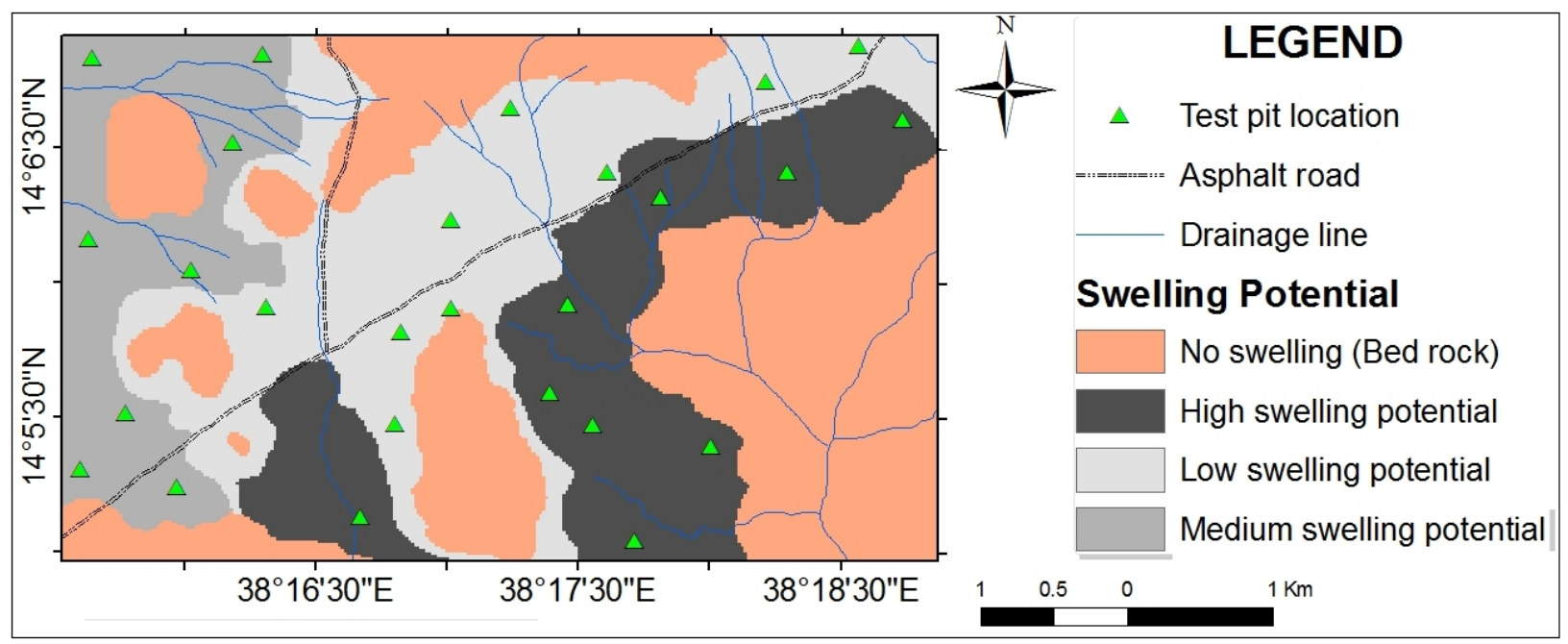

Figure 7. Swelling potential of soils.

\subsubsection{Depth to groundwater table}

Groundwater is one of the main factors governing the stability of foundation excavations as well as the ease and/ or difficulty of the excavation works (Dearman, 1991). The depth to water table layer was prepared by considering the highest elevations of the static water levels. Thus, for the 
observation of the static water level 26 existing hand dug wells and 16 excavated test pits have been considered as ground water level (GWL) observation wells (Fig 8a-c).

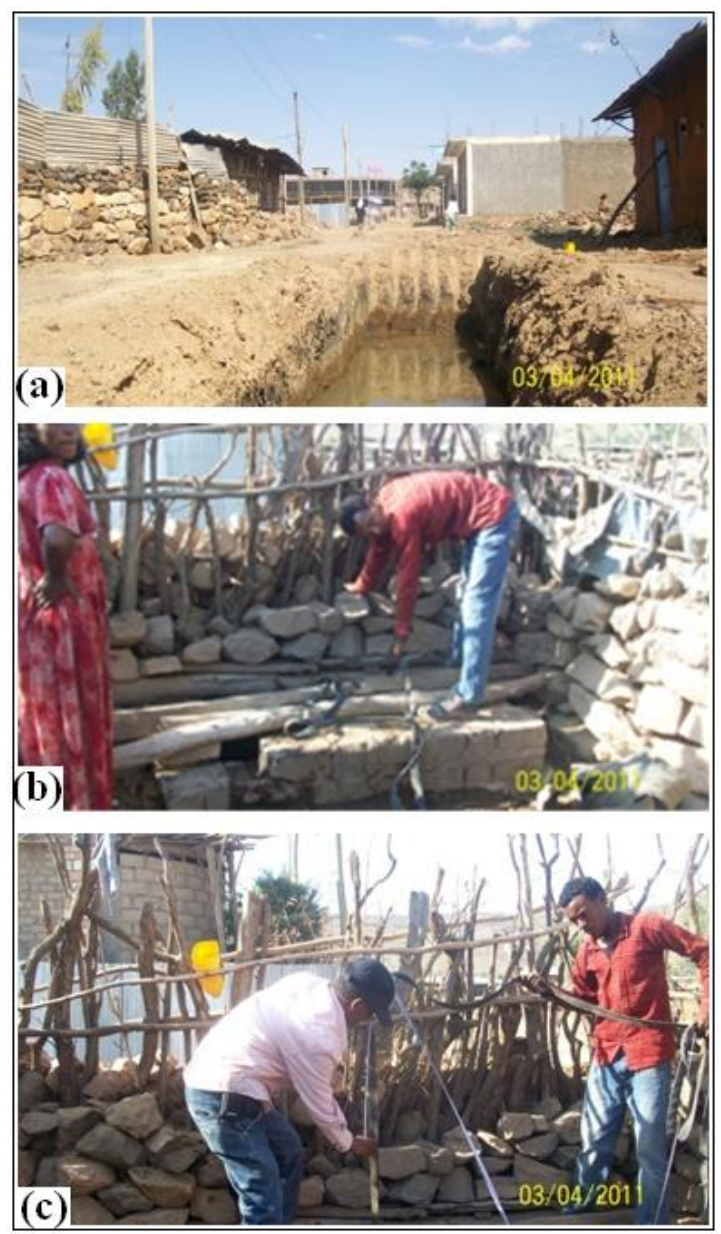

Figure 8. Shallow groundwater in (a) trench excavated for drainage line installation (b) and (c) groundwater level measurement from house hold hand dug wells.

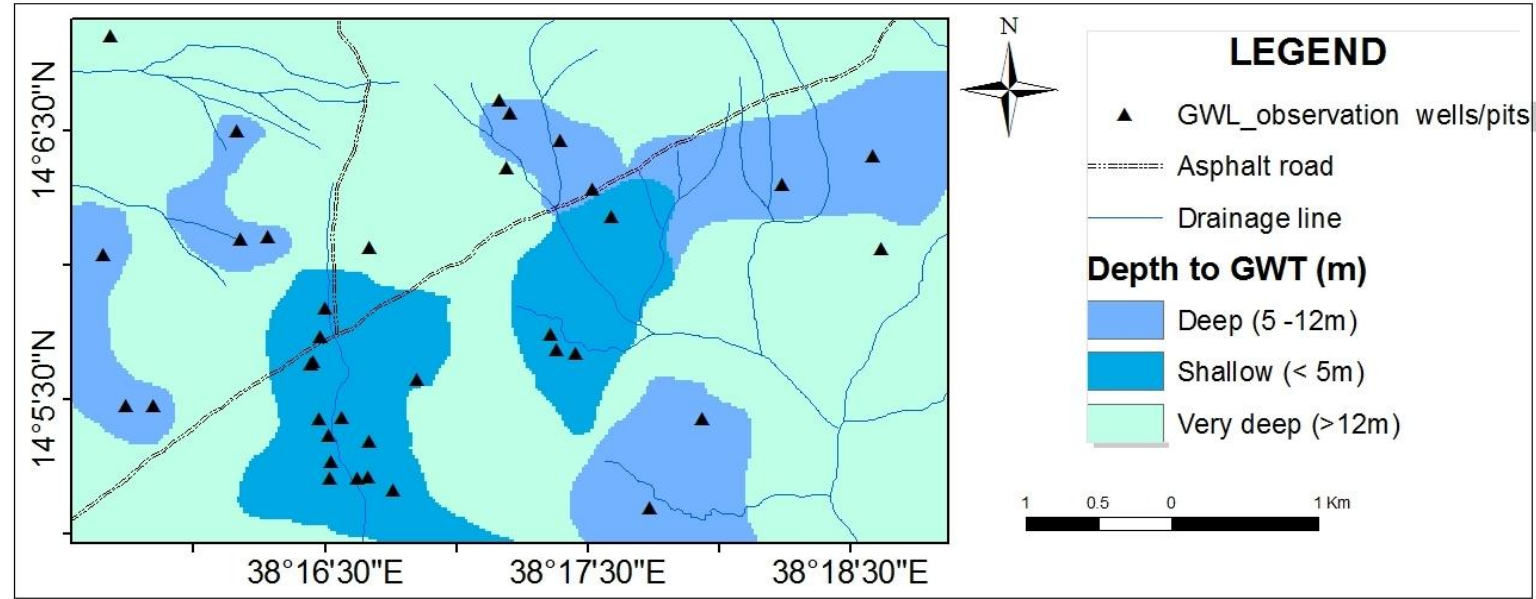

Figure 9. Depth to groundwater table. 
From the hand dug wells and test pits, groundwater levels measured during March, 2011 (the month with the lowest water level) were compiled and depth to water table layer was prepared. A map layer representing the depth to groundwater level is given in figure 9. Areas underlain by shallow $(0-5 \mathrm{~m})$ groundwater table were considered as least favorable, between $5-10 \mathrm{~m}$ as favorable and deeper than $10 \mathrm{~m}$ as the most favorable.

\subsubsection{Flood susceptibility}

From the topographic map of the area and from field investigation, it is observed that there are streams cutting across the city and also there are some recorded previous flood hazard events especially in the south eastern part of the city. Hence, susceptibility to flooding is considered as one of the factors determining the suitability of an area for residential site. The flood susceptibility of the study area was examined in case of thunderstorms of long duration. As flood susceptibility assessment needs detail hydrological analysis and adequate data on past flooding hazard events, this factor is not considered at this moment inthe present model. However, generally areas having slope values less than $2^{\circ}$ and which are found within the major stream floodplains need due attention with respect to flooding hazard.

\subsubsection{Liquefaction potential}

For liquefaction problem to occur the major requirements are presence of non-cohesive soil, water saturation and tremors caused by earthquake. According to the Ethiopian Seismic hazard zone (EBCS-8, 1995), Shire Endasilasie is located in zone 1 (less damaging zone). Hence, seismic hazard is not an important factor in the study area and accordingly the liquefaction problem is not considered in the model.

\section{RESULTS AND DISCUSSION}

\subsection{Geotechnical influencing factors}

There are no universal guidelines for selecting the geotechnical and geo-environmental parameters that influence the suitability of an area for residential purpose. Generally, it is true that during the selection of geotechnical influencing factors, one has to take in to account the nature of the study area and data availability. Moreover, in a GIS-based study, one has also to be sure that the selected factor is operational (i.e. has a certain degree of affinity with geotechnics/geo-environment), complete (i.e. is fairly represented all over the study area), nonuniform (i.e. varies spatially), measurable (i.e. can be expressed by nominal, ordinal, interval or 
ratio scales), and non-redundant (i.e. its effect should not account for double consequences in the final result).

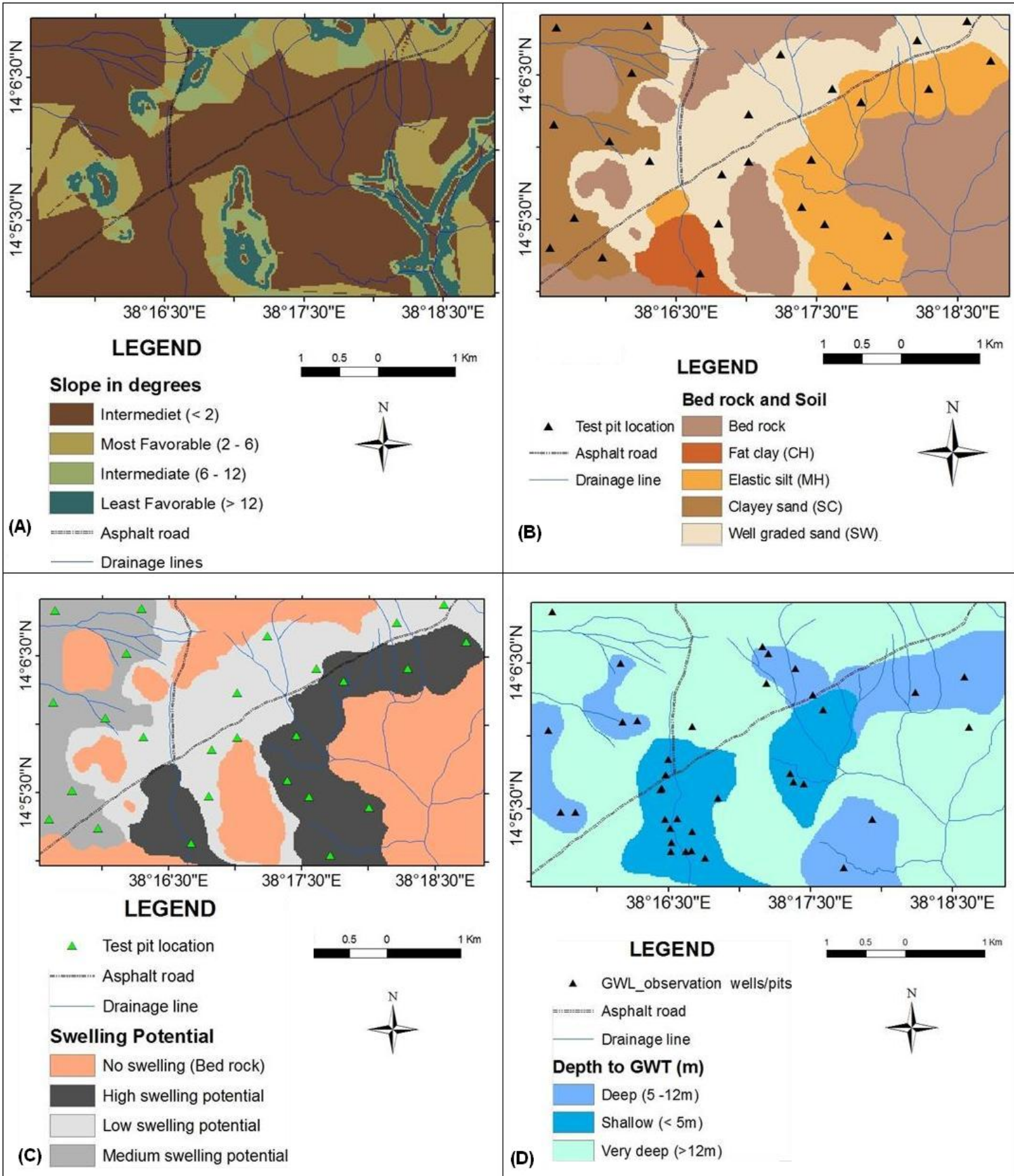

Figure 10. GIS data layers of the geotechnical factors (A) Slope map, (B) Bed rock and soil type map, (C) Swelling potential map and (D) Depth to groundwater level map. 
Based on the above listed criteria, the general literature inputs and data availability, four factors were selected as geotechnical and geo-environmental controlling factors for the geotechnical microzonation for the purpose of assessing suitability of foundation for the residential areas which include: (1) slope gradient, (2) bed rock and soil types, (3) swelling potential of soils, and (4) depth to groundwater table. The map layers for each factor with their respective classes are given in figure 10.

\subsection{Parameter weighting using Analytic Hierarchy Process(AHP)}

Spatial data analysis using GIS is performed by assigning numerical weights to the geotechnical and geo-environmental factors and the classes within each factor. The weights are assigned based on the level of importance of the factors in terms of their influence on the area marked for residential purpose. In the present case, the basis to decide the numerical weightings was (1) the relationships between the suitability of an area for residential purpose and the various influencing factors, (2) data from literature review on causes of failure of buildings and difficulty during construction, and (3) expert judgment on the relative importance/dominance of the different factors in influencing the suitability of an area as residential site.

Different techniques are available to develop parameter weights. When the number of parameters is more than two like in the present case, presenting the information down into simple pair-wise comparisons in which only two factors can be considered at a time can greatly facilitate the weighting process. This technique is called AHP and has been described by Saaty (1980, 1990; Özdemir, 2005 ) in the context of decision making processes. The relative importance (weights) of each factor and each class within a factor, as a determining factor for suitability of an area for residential purpose, has been semi-quantitatively determined by pair-wise comparison using the AHP. The results of the analysis are given in Table 1 and Table 2.

Table 1. Weights (relative) of the different geotechnical influencing factors.

\begin{tabular}{|lccccc|}
\hline $\begin{array}{l}\text { Influencing Factors } \\
\text { (Parameters) }\end{array}$ & $\begin{array}{c}\text { Bed rock and } \\
\text { Soil type }\end{array}$ & $\begin{array}{c}\text { Depth to } \\
\text { GWT }\end{array}$ & $\begin{array}{c}\text { Swelling } \\
\text { Potential } \\
\text { of soils }\end{array}$ & $\begin{array}{l}\text { Slope } \\
\text { gradient }\end{array}$ & $\begin{array}{c}\text { Weight } \\
\text { (\%) }\end{array}$ \\
\hline Bed rock \& Soil type & 1.00 & 2.00 & 3.00 & 5.00 & $\mathbf{4 9}$ \\
\hline Depth to GWT & 0.50 & 1.00 & 2.00 & 3.00 & $\mathbf{2 7}$ \\
\hline Swelling Potential of soils & 0.33 & 0.50 & 1.00 & 1.00 & $\mathbf{1 3}$ \\
\hline Slope gradient & 0.20 & 0.33 & 1.00 & 1.00 & $\mathbf{1 1}$ \\
\hline \multicolumn{1}{l}{ lambda maximum $(\lambda \max )=4.045$} & & consistency ratio $(\mathrm{CR})=1.66 \%$ \\
consistency index $(\mathrm{CI})=1.49 \%$ & & & & $\mathrm{n}=4$ \\
\hline
\end{tabular}


Table 2. Relative weights of each class with in factors (bed rock and soil type, depth to groundwater table, swelling potential of soils, and slope favourability).

\begin{tabular}{|lcccccc|}
\hline $\begin{array}{l}\text { Bed rock } \\
\text { soil type }\end{array}$ & $\begin{array}{l}\text { Bed } \\
\text { rock }\end{array}$ & $\boldsymbol{S W}$ & $\boldsymbol{S C}$ & $\boldsymbol{M H}$ & $\boldsymbol{C H}$ & $\begin{array}{c}\text { Weight } \\
\text { (\%) }\end{array}$ \\
\hline Bed rock & 1.00 & 2.00 & 3.00 & 5.00 & 7.00 & 43 \\
\hline $\mathrm{SW}$ & 0.50 & 1.00 & 2.00 & 4.00 & 5.00 & 26 \\
\hline $\mathrm{SC}$ & 0.33 & 0.50 & 1.00 & 3.00 & 5.00 & 18 \\
\hline $\mathrm{MH}$ & 0.20 & 0.25 & 0.33 & 1.00 & 4.00 & 9 \\
\hline $\mathrm{CH}$ & 0.14 & 0.20 & 0.20 & 0.25 & 1.00 & 4 \\
\hline \multicolumn{2}{c}{$\begin{array}{l}\text { lambda maximum }(\lambda \max )=5.2 \\
\text { Consistency index }(\mathrm{CI})=7.01 \%\end{array}$} & & consistency ratio $(\mathrm{CR})=6.26 \%$ \\
$\mathrm{n}=5$
\end{tabular}

\begin{tabular}{|cccccc|}
\hline $\begin{array}{c}\text { Depth to Groundwater } \\
\text { table }(\boldsymbol{G W T})\end{array}$ & $\mathbf{0 - 5 m}$ & $\mathbf{5 - 1 2 m}$ & $\mathbf{7 1 2 m}$ & & Weight (\%) \\
\hline $0-5 \mathrm{~m}$ & 1.00 & 0.33 & 0.14 & 9 \\
\hline $5-12 \mathrm{~m}$ & 3.00 & 1.00 & 0.50 & 29 \\
\hline$>12 \mathrm{~m}$ & 7.00 & 2.00 & 1.00 & 62 \\
\hline $\begin{array}{c}\text { lambda maximum }(\lambda \max )=3.004 \\
\text { consistency index }(\mathrm{CI})=0.19 \%\end{array}$ & \multicolumn{2}{c}{ consistency ratio $(\mathrm{CR})=0.32 \%$} \\
$\mathrm{n}=3$
\end{tabular}

\begin{tabular}{|lccccc|}
\hline \multicolumn{1}{|c}{$\begin{array}{c}\text { Swelling Potential of } \\
\text { soils }\end{array}$} & $\begin{array}{c}\text { No } \\
\text { swelling }\end{array}$ & $\begin{array}{c}\text { Low } \\
\text { swelling }\end{array}$ & $\begin{array}{c}\text { Medium } \\
\text { swelling }\end{array}$ & $\begin{array}{c}\text { High } \\
\text { swelling }\end{array}$ & $\begin{array}{c}\text { Weight } \\
(\%)\end{array}$ \\
\hline $\begin{array}{l}\text { No swelling } \\
\text { (bed rock) }\end{array}$ & 1.00 & 3.00 & 5.00 & 7.00 & 56 \\
\hline Low swelling & 0.33 & 1.00 & 3.00 & 5.00 & 26 \\
\hline Medium swelling & 0.20 & 0.33 & 1.00 & 3.00 & 12 \\
\hline High swelling & 0.14 & 0.20 & 0.33 & 1.00 & 6 \\
\hline $\begin{array}{c}\text { lambda maximum }(\lambda \max )=4.177 \\
\text { consistency index }(\mathrm{CI})=5.89 \%\end{array}$ & & \multicolumn{2}{c|}{ consistency ratio $(\mathrm{CR})=6.54 \%$} \\
$\mathrm{n}=4$
\end{tabular}

\begin{tabular}{|lcccc|}
\hline \multicolumn{1}{|c}{ Slope favorability } & $\begin{array}{c}\text { Least } \\
\text { favorable } \\
\text { slope class }\end{array}$ & $\begin{array}{c}\text { Mntermediate } \\
\text { slope class }\end{array}$ & $\begin{array}{c}\text { Most } \\
\text { favorable } \\
\text { class }\end{array}$ & $\begin{array}{c}\text { Weight } \\
(\%)\end{array}$ \\
\hline $\begin{array}{l}\text { Least favorable slope } \\
\text { class }\end{array}$ & 1.00 & 0.33 & & 9.14 \\
\hline Intermediate slope class & 3.00 & 1.00 & 0.33 & 24 \\
\hline Most favorable class & 7.00 & 3.00 & 1.00 & 67 \\
\hline $\begin{array}{c}\text { lambda maximum }(\lambda \max )=3.011 \\
\text { consistency index }(\mathrm{CI})=0.54 \%\end{array}$ & & consistency ratio $(\mathrm{CR})=0.93 \%$ \\
$\mathrm{n}=3$
\end{tabular}

\subsection{Geotechnical microzonation map}

The geotechnical microzonation map is the result of the analysis carried out in the raster data model using the weight values of the obtained data layers. In order to produce geotechnical 
microzonation map by Weighted Linear Combination (WLC) model, the primary-level weights corresponding to classes of factors were multiplied by secondary-level or factor weights. In this way a geotechnical microzonation index map (GMIM) which has a continuous scale of numerical values has been generated. The higher the geotechnical microzonation index value of an area is, the more suitable the area as foundation for residential areas.

These continuous numerical values have been divided into suitability classes manually using the natural breaks and result in geotechnical microzonation map with three classes: (1) less suitable for foundation of a settlement area, (2) moderately suitable for foundation of settlement area, (3) more suitable for foundation of settlement area (Fig 11).

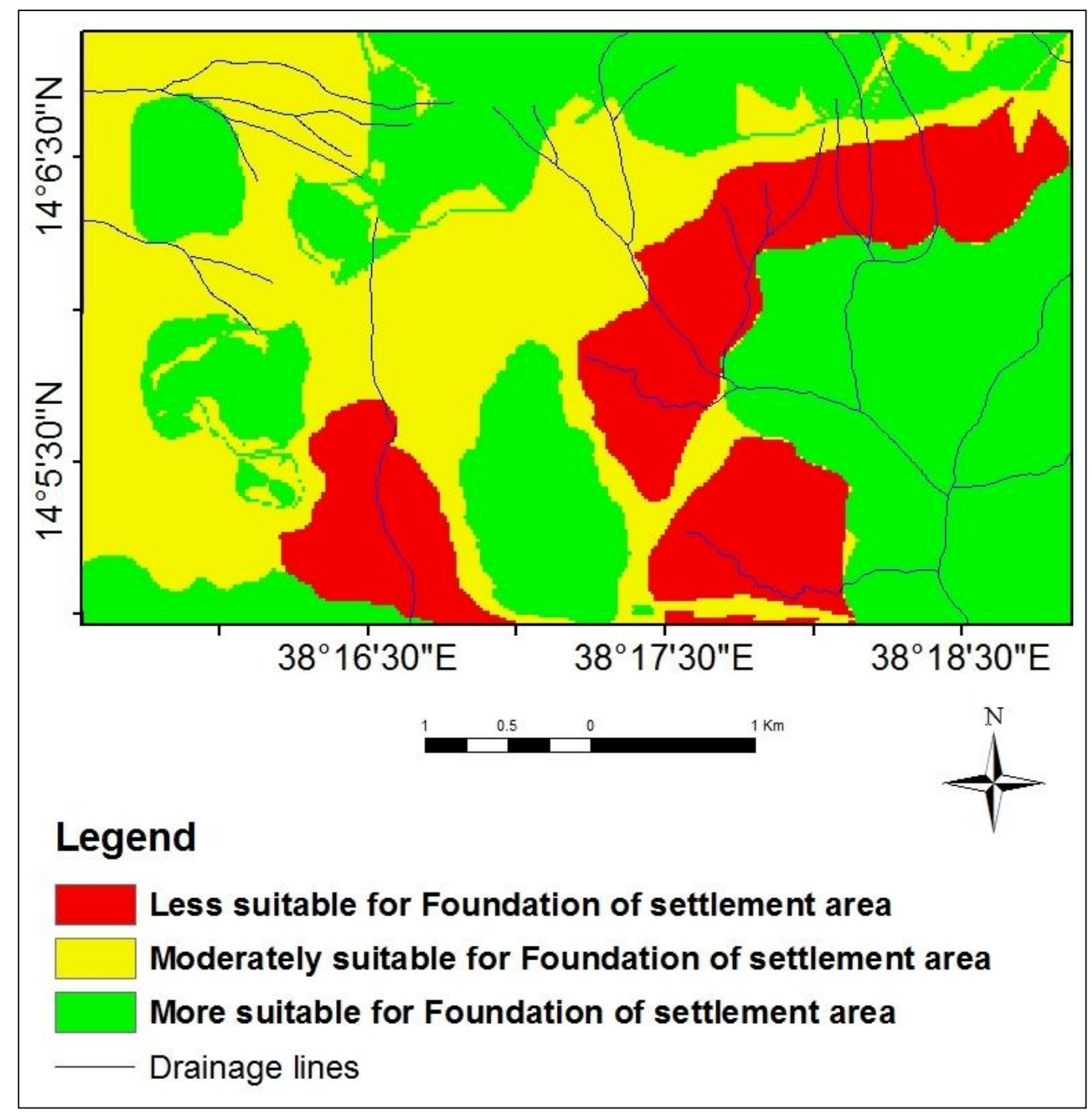

Figure 11. Geotechnical microzonation map indicating different degrees of suitability of an area for foundation of settlement area. 


\section{CONCLUSION}

Application of GIS-based multi-criteria decision analysis is advantageous in having relatively low cost, easy data manipulation, rapidly updating of data and the possibility to produce various new scenarios. In the present case, the slope, bed rock and soil type, depth to groundwater table and swelling potential layers were prepared for the study area. The assignment of the weight (for the factors) and rank values (for each class with in the factors) and the analysis were performed by application of the AHP method.

By combining the influencing factors, the study area was categorized into three different zones based on the foundation suitability for residential areas. The three zones are: (1) less suitable (2) moderately suitable and (3) more suitable areas. The classification result implies that the less suitable zone represents areas requiring detailed geotechnical investigation to be used as foundations for residential area; the moderately suitable zone is a provisional settlement area whereas the more suitable zone is very suitable for settlement. For the already settled areas which are not found in the more suitable zone, the necessity of the precautions must be considered.

The methodology and flowchart used for the chosen area in this study can also be applied to the other locations and to other site selection procedures by reconstructing the necessary parameters/factors appropriately.

The limitations in terms of data sources include: i) limited resolution (topographic map of 1:50,000 scale, limited borehole data, and limited test pit data), depth to groundwater data for only one season, and iii) non-availability of flood susceptibility data. Inclusion of these data however will refine the model further.

As the flood susceptibility was not incorporated in the modeling process, due attention is required to the areas within the flood plain of major drainage lines and with a slope gradient less than 2degrees, whenever the resulting map is used for planning purpose. Furthermore, in using the geotechnical microzonation map as a base for residential site selection and related development plans, a carefull consideration has to be given to the nature of landscape and other related influencing factors which are not included as input data for this model. This is because some of the areas categorized as 'suitable zones' are located in mountainous areas, which might 
face difficulties to get access to infrastructural facilities like access to electricity, water and transport.

\section{ACKNOWLEDGEMENTS}

I would like to thank Mekelle University, particularly College of Natural and Computational Sciences for providing fund in the form of recurrent budget for the research project entitled "(CNCS/RB/28/2011)". I am also thankful to the Shire-Endasilasie city administration for their support and cooperation during my field work. The comments and suggestions by Dr. K. Bheemalingeswara, Dr. V. Govind and Prof. D. Venkata Reddy which have enriched the paper quite significantly are highly appreciated and duly acknowledged.

\section{REFERENCE}

Anon, 1995.Questionnaire reply on the Evaluation of Forest Plantation by the Head, Forest and Wild Life Department, the Transitional Government of Ethiopia, Ministry of Agriculture through FAO Representative dated 21 November 1995 (plantation area upto 1990).

Belton, V \& Stewart, T.J. 2002. Multiple Criteria Decision Analysis-An Integrated Approach. Kluwer Academic Publishers Group, 372p.

Carrara, A., Guzzetti, F., Cardinali, M \& Reichenbach, P. 1999. Use of GIS Technology in the Prediction and Monitoring of Landslide Hazard. Natural Hazards, 20: 117- 135.

Cavaleiro et al., 2006. Geotechnical mapping in the area of Covilhã, Portugal. A methodology using GIS. IAEG, 211:1-8.

Dai, F.C., Lee, C.F \& Zhang, X.H. 2001. GIS-based geo-environmental evaluation for urban land-use planning: a case study. Engineering Geology, 61: 257-271

Dearman, W.R. 1991. Engineering geological mapping. Butterworth-Heinemann Ltd. Oxford, 387 p.

Jankowski, P. 1995. Integrating Geographical Information Systems and multiple criteria decision making methods. International Journal of Geographical Information Systems, 9(3): 251273.

Khizar, H. 2003. Geotechnical zonation and their relation to geology of Pakistan: Pakistan Research Repository. PhD Thesis. University of Punjab Lahore, Pakistan (Higher education commission Pakistan) (unpubl.). 
Kolat, C., Resay, U \& Süzen, M.L. 2012. Development of geotechnical microzonation model for Yenisehir (Bursa, Turkey) located at a seismically active region. Engineering geology, 127: $36-53$.

Özdemir, M.S. 2005. Validity and inconsistency in the Analytic Hierarchy Process. Applied Mathematics and Computation, 161:707-720.

Roch Player, 2000. Using GIS in preliminary geotechnical site investigations for transportation projects. Mid-continent transportation symposium proceedings, (Ames, Iowa ). pp 174177.

Saaty, T.L. 1980. The Analytic Hierarchy Process. New York: McGraw Hill, 350p.

Saaty, T.L. 1990. How to make a decision. The analytic hierarchy process. European Journal of Operational Research, 48: 9-26.

Şener, B., Süzen, M.L \& Doyuran, V. 2006. Landfill site selection by using geographic information systems. Environmental Geology, 49: 376-388.

South African Institute of Engineering Geologists, South African Institution of Civil Engineers. 1997. Guidelines for urban engineering geological investigations. Boutek, CSIR, Pretoria.

Stiff, J.S., Croukamp, L., Keyter, G.J., McKnight, C.L., Tromp, B., Van Rooy, J.L \& Venter, J.P. 1997. Guidelines for Urban Engineering Geological Investigations. South African Institute of Engineering Geologists and the South African Institution of Civil Engineers. Pretoria, 1997.

Sun, C.G. 2010. GIS-Based Assessment of Geotechnical Characteristics Related to Earthquake Motion in a Small Urban Area. International Journal of Energy and Environment, 4(4):105-112.

Süzen, M.L \& Doyuran, V. 2004. A comparison of the GIS based landslide susceptibility assessment methods: multivariate versus bivariate. Environmental Geology, 45(5): 665679.

Tarekegn, T. 1997. The Geology of Axum Area. Memoir, Ethiopian Institute of Geological Surveys, Addis Ababa, No. 9.

Tonkin \& Taylor. 2008. Land zonation mapping and geotechnical assessment level/stability hazard mapping for Hikurangi, Mid Kensington, Whangarei City Centre, East Kamo \& Portland. Report, Whangarei District Council, T\&T Ref: 24010.002 / Volume 1. 